\title{
TECHNOLOGICAL PARAMETERS OF SEEDS APPLIED TO THE SELECTION OF SUPERIOR MOTHER TREES FROM Ormosia discolor SPRUCE EX BENTH
}

Helinara Lais Vieira Capucho $2^{2 *}$, Manuel de Jesus Vieira Lima Júnior ${ }^{3} \odot$, Angela Maria da Silva Mendes ${ }^{4} \odot$, Maria Teresa Gomes Lopes ${ }^{4}$, Amazoneida Sá Peixoto Pinheiro ${ }^{5}$ (?) and Laerte Nogueira da Silva ${ }^{6} \odot$

\footnotetext{
${ }^{1}$ Received on 11.02.2021 accepted for publication on 08.07.2021.

${ }^{2}$ Universidade Federal do Amazonas, Programa de Pós-Graduação em Ciências do Ambiente e Sustentabilidade na Amazônia, Manaus, AM - Brasil. E-mail: <laisrick21@gmail.com>.

${ }^{3}$ Universidade Federal do Amazonas, Departamento de Ciências Florestais, Manaus, AM - Brasil. E-mail: <mjlimajunior@gmail.com>.

${ }^{4}$ Universidade Federal do Amazonas, Departamento de Produção Animal e Vegetal, Manaus, AM - Brasil. E-mail: <45amendes@gmail. com> and <mtglopes@hotmail.com>.

${ }^{5}$ Universidade Federal do Amazonas, Departamento de Ciências Exatas, Manaus, AM - Brasil. E-mail: <neida.pinheiro@gmail.com>.

${ }^{6}$ Centro de Biotecnologia da Amazônia, Manaus, AM - Brasil. E-mail: <slaerte@hotmail.com>.

*Corresponding author.
}

\begin{abstract}
The study on the native species of fast growth and nodulation capacity, Ormosia discolor, intends to conserve genetic resources and make available seed lots of high vigor for seed orchards. This work evaluates the physical and physiological characteristics of seeds from $20 \mathrm{O}$. discolor trees as a subsidy for selecting superior mother trees. Twenty matrices selected from a population in the state of Amazonas were inventoried. Physical tests were performed on the seeds collected, including water content, biometrics, the weight of one thousand seeds, and coat permeability test. For vigor estimates and classification regarding seed storage, the seeds were frozen for five months. The germination test was carried out at a constant temperature of $30{ }^{\circ} \mathrm{C}$. It was used a completely randomized design consisting of 20 mother trees, 4 replicates, and 25 seeds per plot. The germination characteristics evaluated were germination percentage, speed index, mean germination time, and synchronization index. Cut seeds are more efficient for determining water content. All biometric variables are representative for the selection of vigorous lots, with emphasis on geometric diameter, surface area, and sphericity of seeds. Species seeds were classified as orthodox and as having physical dormancy. The protrusion of the primary root is the best morphological characteristic for evaluating germination in the laboratory. The mother trees 7, 16, and 10 showed superior characteristics for dendrometric and technological data, being indicated for marking, phenological monitoring, and planting.
\end{abstract}

Keywords: Native species; Seed analysis; Amazon.

\section{PARÂMETROS TECNOLÓGICOS DE SEMENTES APLICADOS À SELEÇÃO DE ÁRVORES MATRIZES SUPERIORES DE Ormosia discolor SPRUCE EX BENTH}

RESUMO - O estudo sobre a espécie nativa de rápido crescimento e capacidade de nodulação, Ormosia discolor, pretende conservar recursos genéticos e disponibilizar lotes de sementes de alto vigor para pomares de sementes. Este trabalho avalia as características fisicas e fisiológicas de sementes de $20 \boldsymbol{O}$. discolor, como subsídio para a seleção de árvores matrizes superiores. Vinte matrizes selecionadas de uma população do estado do Amazonas foram inventariadas. Foram realizados testes físicos nas sementes coletadas, incluindo teor de água, biometria, peso de mil sementes e teste de permeabilidade do tegumento. Para estimativa do vigor e classificação quanto ao armazenamento, as sementes foram congeladas por cinco meses. Oteste de germinação foi realizado a uma temperatura constante de $30{ }^{\circ} \mathrm{C}$. O delineamento utilizado foi inteiramente casualizado, composto por 20 matrizes, 4 repetições e 25 sementes por parcela. As características de germinação avaliadas foram porcentagem de germinação, índice de velocidade, tempo médio de germinação e índice de sincronização. As sementes cortadas são mais eficientes para determinar o teor de água. Todas as variáveis biométricas são representativas para a seleção de lotes vigorosos, com ênfase no diâmetro geométrico, área superficial e esfericidade das sementes. As sementes das espécies foram classificadas como ortodoxas e com dormência

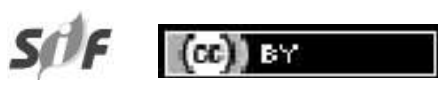

Revista Árvore 2021;45:e4536 http://dx.doi.org/10.1590/1806-908820210000036 
fisica. A protrusão da raiz primária é a melhor característica morfológica para avaliação da germinação em laboratório. As matrizes 7, 16 e 10 apresentaram características superiores para dados dendrométricos e tecnológicos, sendo indicadas para marcação, monitoramento fenológico e plantio.

Palavras-Chave: Espécie nativa; Análise de semente; Amazônia.

\section{INTRODUCTION}

The Amazon is recognized as the largest tropical forest in South America, covering about 550 million hectares, of which $60 \%$ are in Brazil. However, the Amazon rainforest has been going through an environmental setback over the last few decades, caused by changes in land use that affect their great biodiversity, and richness in genetic resources (Araújo Neto et al., 2018). In general, this implies a decrease in plant species, even before knowing about their reproduction, and consequently, their replacement to the environment.

Data from the National Institute for Space Research (NISR) point out that there was a $34.5 \%$ increase in alerts for deforestation between august 2019, and july 2020 compared to those in the previous period, and $9,205 \mathrm{~km}^{2}$ of deforested areas were recorded in the Legal Amazon (INPE, 2020). Therefore, the growing conservationist pressure, and the intensification of inspection to compliance with the legislation demand a high number of seeds, a fundamental product for forest recovery programs. The regulation of Law No. 10,711 of August 5, 2003 (Brasil, 2003), Decree No. 5,153 of July 23, 2004 (Brasil, 2004), Normative Instruction $\mathrm{N}^{\circ} .17$ of April 28, 2017 (Brasil, 2017), and more recently, the Ordinance $N^{\circ} .42$ of February 18, 2020 (Brasil, 2020) are highlighted as the main government support.

The National System of Seeds and Seedlings (Law $\mathrm{N}^{\circ}$. 10,711), whose main objective is to guarantee the identity, quality, and reproduction of the plant multiplication material, produced, used, and commercialized in Brazil, encourages reforestation with native species for conservation from an adequate supply of high-quality seeds for seedling production. In addition, it promotes the science, and technology of collection, identification, processing, storage, trade, inspection, and criminal measures related to the production, and commercialization of seeds, and seedlings.
In this scenario, the phenotypic selection of the seed-bearing tree, defined by Law 10,711 (Brasil, 2003) as a plant that supplies propagating material, is one of the first criteria for obtaining quality seeds as required by Normative Instruction $\mathrm{N}^{\mathrm{o}} .17$ of April 28, 2017 (Brasil, 2017). The basic principle is that adult trees with good phenotypic characteristics should be kept in the forest to provide abundant, and superior quality seeds, guaranteeing the genetic diversity of the area (Abreu et al., 2018). As most of the phenotypic, and genotypic characteristics are hereditary, their study is essential for the marking, and monitoring of trees that will ensure the transfer of superior characteristics to their offspring.

To assess the genetic, physical, physiological, and sanitary quality of a seed lot, the official seed analysis laboratories use standardized protocols, contained in the Rules for Seed Analysis - RSA (Brasil, 2009), and in the Instructions for Forest Seed Analysis (Brasil, 2013), to perform physical tests, germination tests, and vigor assessment. These protocols need to be constantly updated when new species, and cultivars are launched in the seed production chain. For this, studies on seed technology are essential for the inclusion of native species in the RSA.

According to Calvi and Ferraz (2014), out of 788 species of economic interest that occur in the Amazon, whether native or introduced, there is information on the evaluation of seed quality for only one third of the species, and studies were found that defined the tolerance to desiccation of seeds only for $44 \%$ of species; the authors point out that this information is basic for any management of these seeds.

Assessing the vigor of a seed lot is essential, as quality seeds can establish the seedling in the field, and its potential for storage. Perry (1980) describes that vigor is a physiological characteristic determined by the genotype, and modified by the environment, and that the influence of vigor can persist throughout the life of the plant, and affect production.

Revista Árvore 2021;45:e4536 
Ormosia discolor Spruce. ex Benth. of the Fabaceae family is a tree component native to the Amazon, not endemic to Brazil, and has a confirmed geographical distribution in the north of the state of Amazonas (Cardoso and Meireles, 2015). The species occurs in terra firme forest, in sandy soils of high scrubs (Rudd, 1965). In the interior of Amazonas, the species is recognized for its seeds of red colors, or red with irregular black marks, usually used in local crafts (Rudd, 1965). The seeds have a hard coat making it difficult to germinate, and the seedlings developed in a nursery have symbiotic nodulation, a desirable characteristic for forest restoration (Moreira et al., 1992).

In this context, and knowing the importance of technical information about native seeds for purposes of forest restoration, and conservation of genetic resources, this study evaluated the physical, and physiological characteristics of 20 lots (matrices) of Ormosia discolor seeds as a subsidy for the selection of superior matrices.

\section{MATERIAL AND METHODS}

\subsection{Seed collection area and Matrix characterization}

Matrix selection was carried out from a native population of $O$. discolor located in the municipality of Autazes, in the state of Amazonas (3'34'49" S, 59 7'53" W). Twenty open pollination trees were inventoried, equidistant at least 100 meters. Each selected matrix was georeferenced for the elaboration of a monitoring map, and registered in a matrix tree form with dendrometric information, and phytosanitary status, besides data on the position of the matrix, and soil characteristics, according to the form prepared by the Amazon Seed Network, and adapted by the Center for Native Seeds of Amazonas - CNSAM (Pinto et al., 2016).

In each matrix, approximately 3.000,00 fruits were collected to carry out the tests. In the collection area, pre-processing of the fruits was carried out, which are dried, and dehiscent aiming at the removal of the seeds trapped by the funicle. The seeds were processed, stored in batches, and analyzed at CNSAM at the Federal University of Amazonas (FUA).

\subsection{Seed water content}

The water content was determined right after the receipt of the lots (initial water content) in an oven set to $105^{\circ} \mathrm{C} \pm 3{ }^{\circ} \mathrm{C}$ for 24 hours, as specified in the RSA (Brasil, 2009). The water content of the seeds in each batch was determined with two subsamples of 4-5 $\mathrm{g}$ of whole seeds, and; due to its impermeable coat, it was also determined with two subsamples of twenty-three cut seeds. The results were expressed as a percentage based on the wet mass.

\subsection{Seed processing}

The seed processing consisted of cleaning, and selecting the seeds by immersing them in distilled water for $24 \mathrm{~h}$ to remove field impurities, and predated (imbibed), immature, and dead seeds. After natural drying, the seeds were packed in sealed plastic bags, identified according to the original matrix, and placed in a cold chamber at $15^{\circ} \mathrm{C}$ for five months until the beginning of the experiments.

\subsection{Weight of one-thousand seeds and number of seeds per kilo}

To determine the weight of one-thousand seeds (WOTS), and the number of seeds per kilo, the procedures prescribed in the Instructions for Analysis of Forest Seeds (Brasil, 2013) were followed.

\subsection{Seed biometrics}

Thirty units of each seed lot were sampled for biometric evaluation. A digital caliper $(0.01 \mathrm{~mm})$ was used to measure the length (measured between the base, and the apex of the seed), width (measured perpendicular to the length), and thickness (measured against the width), and to obtain the fresh weight, an electronic scale $(0.001 \mathrm{~g})$ was used. From the biometric data, the geometric mean diameters of seeds (GMD), seed aspect ratio (Ar), volume (V), seed surface area $(\mathrm{Sa})$, and seed sphericity $(\varnothing)$ were determined according to those obtained in Pontes et al. (2018).

\subsection{Seed coat permeability test}

The seed coat permeability test was performed with four replications of five seeds. The initial seed mass of each repetition was measured, and, afterwards, they were immersed in $100 \mathrm{~mL}$ of distilled water, kept at room temperature $\left( \pm 25^{\circ} \mathrm{C}\right)$. Every 24 hours the seeds were removed from the water, dried with paper towels, and weighed again for 15 days.

Revista Árvore 2021;45:e4536 


\subsection{Freeze test}

To assess vigor, 100 seeds per batch/matrix with an average water content of $7 \%$ were frozen for five months in a refrigerator at a temperature below 0 ${ }^{\circ} \mathrm{C}$, according to procedures adapted from Hong and Ellis (1996). After the freezing period, seeds were submitted to the germination test.

\subsection{Germination test}

To determine the viability, and vigor of seeds after desiccation, and freezing, the seeds were subjected to mechanical scarification, after detecting the impermeability of the integument, which consisted of cutting on the side opposite the hilum. Before sowing, asepsis was performed with a $5 \%$ solution of sodium hypochlorite $(\mathrm{NaClO})$ for 5 minutes, and washing with distilled water (Brasil, 2013).

Germination tests were carried out in germination chambers with $20 \mathrm{~W}$ fluorescent lamps adjusted to a constant temperature of $30^{\circ} \mathrm{C}$, and 12hour photoperiod. The experiment was a completely randomized design, formed by 20 matrices, 4 replicates, and 25 seeds per plot. Sowing was carried out on an autoclaved germitest paper roll (PR) according to Brasil (2013).

The evaluations were made daily up to 30 days after sowing, analyzing two germination criteria: the radicle protrusion $(2 \mathrm{~mm})$, and the formation of normal seedling with developed root, and shoot. The objective of evaluating both criteria was to infer the time required for the formation of a normal seedling in seeds submitted to the vigor test. To determine the germination percentage (GP), seeds with primary root $(2 \mathrm{~mm})$ were considered germinated, with their value corresponding to the percentage of germinated seeds until the end of the experiment. It was also determined as a characteristic of germination: the mean germination time (MGT), germination synchronization index (GSI), and germination speed index (GSpI), according to Santos et al. (2020).

The data obtained for the evaluated characters were submitted to the Lilliefors normality test to check the need for data transformation. Only the GP values did not show normality, and therefore, they were transformed according to the equation: arcsine $\sqrt{ } \mathrm{x} / 100$, where: $\mathrm{x}$ corresponds to the percentage of germinated seeds. The batches were compared using descriptive statistics, and analysis of variance followed by the comparison of means performed by the Scott and Knott test at 5\% probability. For the selection of the best matrices based on the vigor indexes, the selection index of Mulamba and Mock (1978) was used as a reference. The selection index hierarchizes the genotypes, initially, for each characteristic, assigning higher absolute values to those with better performance. Subsequently, the values obtained for each characteristic are added, obtaining the sum of "ranks", which marks the classification of the genotypes. For the germination data, the same economic weight (1) was used for all characteristics, except for GP, which had weight (2) because it is the most important characteristic in tests of this nature. These data were processed in the genetics, and experimental statistics software, Genes (Cruz, 2013).

\subsection{Principal component analysis}

Exploratory multivariate statistical techniques were applied through Principal Component Analysis (PCA) to discriminate among a set of seventeen variables or parameters the ones that most contribute to characterize the seed lots of the species. Multivariate analyzes were performed only after variable standardization, each with a mean of 0 , and variance 1 . The data were tested for normality, and subsequently processed using the Past ${ }^{\circledR}$ software.

\section{RESULTS}

According to the dendrometric analysis for matrices of $O$. discolor, thirteen among the 20 matrices selected have a bifurcated stem at the base. The matrices have a stem circumference with a variation of 27.7 to $55.0 \mathrm{~cm}$, and height between 5.0 to $16.0 \mathrm{~m}$. For canopy of trees, height ranged from 1.0 to $8.0 \mathrm{~m}$, and similarly, the diameter ranged between 1.5 to $10.0 \mathrm{~m}^{2}$.

The water content of seeds with whole samples varied between $4.5-7.1 \%$ of water, and in samples with cut seeds, $7.9-10.2 \%$ of water. The average difference between the two methods was $3.2 \%$.

The analysis of variance for the biometric data showed a difference between means of seed dimensions for each lot. The highest frequency of seeds among lots for the variable weight was found

Revista Árvore 2021;45:e4536 
Table 1 - Estimated means of biometric data obtained from wet weight (g), length (mm), width (mm), and thickness (mm) of seeds, and variables weight of one-thousand seeds (WOTS), and number of seeds per kilo evaluated in twenty matrices of Ormosia discolor.

Tabela 1 - Médias estimadas de dados biométricos obtidos a partir do peso úmido ( $\mathrm{g})$, comprimento (mm), largura (mm) e espessura (mm) de sementes e variáveis peso de mil sementes (PMS) e número de sementes por quilo avaliadas em vinte matrizes de Ormosia discolor.

\begin{tabular}{|c|c|c|c|c|c|c|c|c|c|c|}
\hline Matrix & Ws (g) & $\mathrm{Ls}(\mathrm{mm})$ & Wths (mm) & Ts (mm) & WOTS(g) & $\mathrm{Ns} / \mathrm{Kg}$ & $\mathrm{GMD}(\mathrm{mm})$ & $\varnothing(\%)$ & $\operatorname{Ar}(\%)$ & $\overline{\mathrm{V} / \mathrm{Ss}(\mathrm{mm})}$ \\
\hline 1 & 0.18 & 6.30 & 7.29 & 5.63 & 173.4 & 4612.6 & 6.25 & 99.3 & 1.16 & 1.10 \\
\hline 2 & 0.19 & 7.66 & 6.61 & 5.19 & 193.8 & 4128.7 & 6.29 & 82.1 & 0.86 & 1.11 \\
\hline 3 & 0.30 & 9.25 & 8.41 & 5.59 & 295.1 & 2710.8 & 7.42 & 80.2 & 0.91 & 1.31 \\
\hline 4 & 0.17 & 7.83 & 7.16 & 4.91 & 181.1 & 4417.2 & 6.39 & 81.5 & 0.91 & 1.13 \\
\hline 5 & 0.21 & 7.44 & 7.40 & 5.70 & 219.8 & 3639.7 & 6.66 & 89.5 & 0.99 & 1.18 \\
\hline 6 & 0.25 & 7.30 & 8.43 & 6.00 & 238.5 & 3353.8 & 7.02 & 96.2 & 1.16 & 1.24 \\
\hline 7 & 0.26 & 7.84 & 8.24 & 6.04 & 239.4 & 3341.5 & 7.16 & 91.4 & 1.05 & 1.27 \\
\hline 8 & 0.24 & 8.44 & 7.97 & 5.63 & 215.6 & 3709.1 & 7.09 & 84.1 & 0.94 & 1.25 \\
\hline 9 & 0.18 & 7.10 & 7.21 & 5.06 & 170.3 & 4697.2 & 6.26 & 88.2 & 1.02 & 1.10 \\
\hline 10 & 0.20 & 6.68 & 8.39 & 5.63 & 173.3 & 4617.1 & 6.68 & 100.0 & 1.26 & 1.18 \\
\hline 11 & 0.20 & 7.58 & 7.11 & 5.08 & 188.6 & 4241.7 & 6.37 & 84.1 & 0.94 & 1.12 \\
\hline 12 & 0.28 & 8.36 & 8.09 & 5.97 & 263.5 & 3035.6 & 7.24 & 86.7 & 0.97 & 1.28 \\
\hline 13 & 0.24 & 7.87 & 8.37 & 5.62 & 233.9 & 3420.2 & 7.04 & 89.4 & 1.06 & 1.24 \\
\hline 14 & 0.21 & 7.99 & 7.70 & 5.38 & 187.7 & 4262.8 & 6.78 & 84.9 & 0.96 & 1.20 \\
\hline 15 & 0.25 & 7.32 & 7.51 & 6.05 & 225.3 & 3551.3 & 6.80 & 92.8 & 1.03 & 1.20 \\
\hline 16 & 0.18 & 7.51 & 7.19 & 5.26 & 171.5 & 4665.5 & 6.45 & 85.9 & 0.96 & 1.14 \\
\hline 17 & 0.22 & 8.06 & 7.44 & 5.43 & 204.3 & 3915.8 & 6.75 & 83.7 & 0.92 & 1.19 \\
\hline 18 & 0.18 & 7.43 & 7.29 & 5.23 & 165.1 & 4846.6 & 6.45 & 86.7 & 0.98 & 1.14 \\
\hline 19 & 0.19 & 7.52 & 6.87 & 5.23 & 179.9 & 4446.2 & 6.35 & 84.4 & 0.91 & 1.12 \\
\hline 20 & 0.20 & 7.88 & 7.08 & 5.42 & 180.1 & 4441.3 & 6.59 & 83.5 & 0.90 & 1.16 \\
\hline Mean & 0.22 & 7.67 & 7.59 & 5.50 & 205.0 & 4002.8 & 6.70 & 87.7 & 0.99 & 1.18 \\
\hline $\mathrm{CV}(\%)^{2}$ & 15.7 & 5.41 & 5.36 & 6.07 & 17.3 & 15.5 & 5.4 & 6.5 & 0.10 & 0.07 \\
\hline
\end{tabular}

Ws: weight; Ls: length; Wths: width; Ts: thickness; WOTS: weight of one-thousand seeds; Ns/Kg: number of seeds per kilo; GMD: geometric mean diameter; Ø: sphericity; Ar: aspect ratio; V/Ss: seed volume/surface area ratio 1 Experimental variation coefficient.

Ps: peso; Cs: comprimento; Ls: largura; Es: espessura; PMS: peso de mil sementes; $\mathrm{Ns} / \mathrm{Kg}$ : número de sementes por quilo; DMG: diâmetro médio geométrico; Ø: esfericidade; Ra: relação de aspecto; V/As: razão volumel área superficial da semente 'Coeficiente de variação experimental.

for the class 0.17 to $0.20 \mathrm{~g}$ (45\% of the lots); length between 7.57 to $8.17 \mathrm{~mm}(50 \%$ of the lots); width between the class of 6.97 to $7.34 \mathrm{~mm}$ (35\% of the lots), and the thickness between 5.60 to $5.82 \mathrm{~mm}$ (25\% of the lots). The weight of one-thousand seeds (WOTS) varied from 165.1 to $295.1 \mathrm{~g}$, with $55 \%$ of the lots between 165 to $194 \mathrm{~g}$; and the number of seeds per kilo between $2,710.8$ to $4,846.6$ with $35 \%$ of the lots varying between $4,148.0$ to $4,626.0$ seeds (Table 1 ).

According to the analysis of the geometric mean diameter of the seeds (GMD), this parameter had a higher frequency between the class 6.46 to $6.65 \mathrm{~mm}$ (35\% of the lots). The highest frequency of class for seed sphericity (Ø) was analyzed between classes 80.2 to $84.4 \%$ ( $40 \%$ of the lots). The seed aspect ratio was found most frequently between classes 0.86 to $0.99 \%$ (65\% of the lots). The volume/surface area ratio of the seed showed the highest frequency of class between 1.10 to $1.14 \mathrm{~mm}$ ( $40 \%$ of the lots).

During 15 days of observation, the coat impermeability to water was detected in the seeds of
$O$. discolor, and there was no change in weight in the seeds subjected to imbibition. After pre-germinative treatment, the beginning of germination was observed on the 4th day after sowing for the radicle protrusion criterion; with peak germination on the 15 th day in $62 \%$ of the total seeds. Seedling formation started on the 19th day, and peaked with $53 \%$ of the seeds on the 27 th day. During the germination test, fungal colonization occurred soon after imbibition in all seed lots, causing rot or death of some of them. It is worth mentioning that the colonization was less than that observed in the germination of seeds before the freezing test. Six genera were identified: Aspergillus spp., Penicillium spp., Trichoderma sp., Colletotrichum spp., Lasiodiplodia spp., and Rizhopus spp.

The seeds of $O$. discolor, submitted to the freezing test, maintained viability for all lots, and the germination percentage was similar or higher than that before freezing. From the combined results of all germination characteristics, through the sum 
Table 2 - Estimated means of the physiological potential of seeds submitted to the freeze resistance test, and evaluated under environment at $30^{\circ} \mathrm{C}$, of twenty matrices of Ormosia discolor obtained by the percentage of germination (GP), mean germination time (MGT), germination synchronization index (GSI), and germination speed index (GSpI).

Tabela 2 - Médias estimadas do potencial fisiológico de sementes submetidas ao teste de resistência ao congelamento e avaliadas em ambiente de $30^{\circ} \mathrm{C}$, de vinte matrizes de Ormosia discolor, obtidas pela porcentagem de germinação (PG), tempo médio de germinação (TMG), índice de sincronização de germinação (ISG) e indice de velocidade de germinação (IVG).

\begin{tabular}{|c|c|c|c|c|c|c|c|c|}
\hline \multirow[t]{2}{*}{ Matrizes } & \multicolumn{8}{|c|}{ Variables analyzed ${ }^{1}$} \\
\hline & GP & & MGT & & GSI & & GSpI & \\
\hline 1 & $0.59(31.0 \%)$ & $\mathrm{d}$ & 5.83 & $\mathrm{c}$ & 1.71 & $\mathrm{~b}$ & 2.16 & $\mathrm{c}$ \\
\hline 2 & $1.15(83.0 \%)$ & $\mathrm{a}$ & 5.75 & $\mathrm{c}$ & 1.91 & $\mathrm{~b}$ & 3.93 & $\mathrm{a}$ \\
\hline 3 & $0.86(57.0 \%)$ & $\mathrm{b}$ & 5.76 & $\mathrm{c}$ & 1.54 & $\mathrm{c}$ & 3.20 & $\mathrm{~b}$ \\
\hline 4 & $0.79(50.0 \%)$ & $\mathrm{c}$ & 6.22 & $\mathrm{c}$ & 2.05 & $\mathrm{a}$ & 2.60 & $\mathrm{~b}$ \\
\hline 5 & $0.77(48.0 \%)$ & $\mathrm{c}$ & 6.12 & $\mathrm{c}$ & 1.88 & $\mathrm{~b}$ & 2.37 & $\mathrm{c}$ \\
\hline 6 & $0.93(64.0 \%)$ & $\mathrm{b}$ & 6.95 & $\mathrm{~b}$ & 2.13 & $\mathrm{a}$ & 2.39 & $\mathrm{c}$ \\
\hline 7 & $1.17(84.0 \%)$ & $\mathrm{a}$ & 6.72 & $\mathrm{~b}$ & 2.10 & $\mathrm{a}$ & 3.45 & a \\
\hline 8 & $0.46(20.0 \%)$ & $\mathrm{d}$ & 5.72 & $\mathrm{c}$ & 1.45 & $\mathrm{c}$ & 1.48 & $\mathrm{~d}$ \\
\hline 9 & $0.99(70.0 \%)$ & $\mathrm{b}$ & 5.43 & $\mathrm{c}$ & 1.90 & $\mathrm{~b}$ & 3.66 & $\mathrm{a}$ \\
\hline 10 & $0.57(29.0 \%)$ & $\mathrm{d}$ & 6.94 & $\mathrm{~b}$ & 1.81 & $\mathrm{~b}$ & 1.20 & $\mathrm{~d}$ \\
\hline 11 & $1.19(86.0 \%)$ & $\mathrm{a}$ & 8.04 & $\mathrm{a}$ & 2.27 & $\mathrm{a}$ & 2.84 & $\mathrm{~b}$ \\
\hline 12 & $1.02(72.0 \%)$ & $\mathrm{b}$ & 6.34 & $\mathrm{c}$ & 2.03 & $\mathrm{a}$ & 3.18 & $\mathrm{~b}$ \\
\hline 13 & $1.02(72.0 \%)$ & $\mathrm{b}$ & 6.80 & $\mathrm{~b}$ & 2.20 & $\mathrm{a}$ & 2.92 & $\mathrm{~b}$ \\
\hline 14 & $0.70(42.0 \%)$ & $\mathrm{c}$ & 6.57 & $\mathrm{~b}$ & 1.96 & $\mathrm{~b}$ & 1.94 & c \\
\hline 15 & $1.04(74.0 \%)$ & $\mathrm{b}$ & 7.72 & $\mathrm{a}$ & 2.35 & $\mathrm{a}$ & 2.68 & b \\
\hline 16 & $1.02(72.0 \%)$ & $\mathrm{b}$ & 5.45 & $\mathrm{c}$ & 1.90 & b & 3.59 & a \\
\hline 17 & $0.95(66.0 \%)$ & $\mathrm{b}$ & 6.62 & $\mathrm{~b}$ & 2.27 & $\mathrm{a}$ & 2.96 & $\mathrm{~b}$ \\
\hline 18 & $0.91(62.0 \%)$ & $\mathrm{b}$ & 5.66 & $\mathrm{c}$ & 2.06 & $\mathrm{a}$ & 2.10 & $\mathrm{~b}$ \\
\hline 19 & $1.12(80.0 \%)$ & $\mathrm{a}$ & 5.91 & $\mathrm{c}$ & 1.89 & $\mathrm{~b}$ & 3.80 & a \\
\hline 20 & $0.64(36.0 \%)$ & d & 6.67 & $\mathrm{~b}$ & 2.16 & $\mathrm{a}$ & 1.71 & d \\
\hline Mean $^{2}$ & $0.89(59.9 \%)$ & & 6.36 & & 1.98 & & 2.75 & \\
\hline $\mathrm{CV}(\%)^{3}$ & 13.19 & & 9.11 & & 12.17 & & 16.17 & \\
\hline
\end{tabular}

${ }^{1}$ Means followed by the same letter, in each column, belong to the same group according to the grouping criteria of Scott and Knott at $5 \%$ probability; ${ }^{2} \mathrm{Mean}$ of the GP-transformed data (arcsine of the root of $\mathrm{x} / 100$ ), and original in percentage; ${ }^{3}$ Experimental coefficient variation.

${ }^{1}$ Médias seguidas de mesma letra, em cada coluna, pertencem a um mesmo grupo de acordo com o critério de agrupamento de Scott e Knott, a $5 \%$ de probabilidade; ${ }^{2}$ Média dos dados da PG transformada (arcoseno da raiz de x/100) e original em porcentagem; ${ }^{3}$ Coeficiente de variação experimental.

Table 3 - Rank of matrices with the best results obtained for dendrometric variables, and technological parameters of twenty matrices of Ormosia discolor.

Tabela 3 - Rank de matrizes com os melhores resultados obtidos para variáveis dendrométricas e parâmetros tecnológicos de vinte matrizes de Ormosia discolor.

\begin{tabular}{|c|c|c|c|c|c|c|c|c|c|c|}
\hline \multicolumn{11}{|c|}{ Variables analyzed } \\
\hline $\mathrm{CAP}(\mathrm{cm})$ & $\mathrm{NF}$ & $\mathrm{TH}(\mathrm{m})$ & $\mathrm{CH}(\mathrm{m})$ & $\mathrm{CD}(\mathrm{m})$ & MCws(\%) & $\operatorname{MCcs}(\%)$ & WOTS (g) & $\mathrm{NS} / \mathrm{kg}$ & $\operatorname{Ar}(\%)$ & $\mathrm{V} / \mathrm{Ss}(\mathrm{mm})$ \\
\hline 16 & 3 & 8 & 5 & 15 & 14 & 16 & 12 & 9 & 10 & 3 \\
\hline 2 & 14 & 5 & 7 & 7 & 2 & 14 & 7 & 16 & 1 & 12 \\
\hline 10 & 7 & 7 & 10 & 13 & 16 & 10 & 6 & 10 & 6 & 7 \\
\hline 8 & 19 & 16 & 15 & 16 & 1 & 13 & 13 & 1 & 13 & 8 \\
\hline Ws (g) & $\mathrm{Ls}(\mathrm{mm})$ & \multicolumn{2}{|c|}{ Wths (mm) } & $\mathrm{Ts}(\mathrm{mm})$ & GP (\%) & MGT (days) & GSI & GSpI & $\mathrm{GMD}(\mathrm{mm})$ & $\varnothing(\%)$ \\
\hline$\overline{12}$ & 8 & \multicolumn{2}{|c|}{3} & 7 & 7 & 16 & 3 & 19 & 3 & $\overline{10}$ \\
\hline 7 & 12 & \multicolumn{2}{|c|}{10} & 6 & 2 & 18 & 1 & 9 & 12 & 1 \\
\hline 6 & 17 & \multicolumn{2}{|c|}{13} & 12 & 19 & 8 & 10 & 16 & 7 & 6 \\
\hline 15 & 14 & \multicolumn{2}{|c|}{7} & 5 & 15 & 2 & 5 & 7 & 8 & 15 \\
\hline
\end{tabular}

content of whole seed; MCCs: moisture content of cut seed; WOTS: weight of one-thousand seeds; NS/Kg: number of seeds per kilo; Ar: aspect ratio; V/As: volume/ surface area ratio; Ws: weight; Ls: length; Wths: width; Ts: thickness; GP: germination percentage; MGT: mean germination time: GSI: germination synchronization index; GSpI: germination speed index; GMD: geometric mean diameter; Ø: sphericity of the seed.

CAP: circunferência medida a 1,30 cm do solo; NF: número de fustes; AT: altura total; AC: altura da copa; DC: diâmetro da copa; TUsi: teor de umidade semente inteira; TUsc: teor de umidade semente cortada; PMS: peso de mil sementes; NS/Kg: número de semente por quilo; Ra: relação de aspecto; V/As: razão volume/área superficial; Ps: peso; Cs: comprimento: Ls: largura: Es: espessura: PG: porcentagem de germinação: TMG: tempo médio de germinação: ISG: indice de sincronização da germinação; IVG: indice de velocidade de germinação; DMG: diâmetro médio geométrico; Ø: esfericidade da semente.

\section{Revista Árvore 2021;45:e4536}




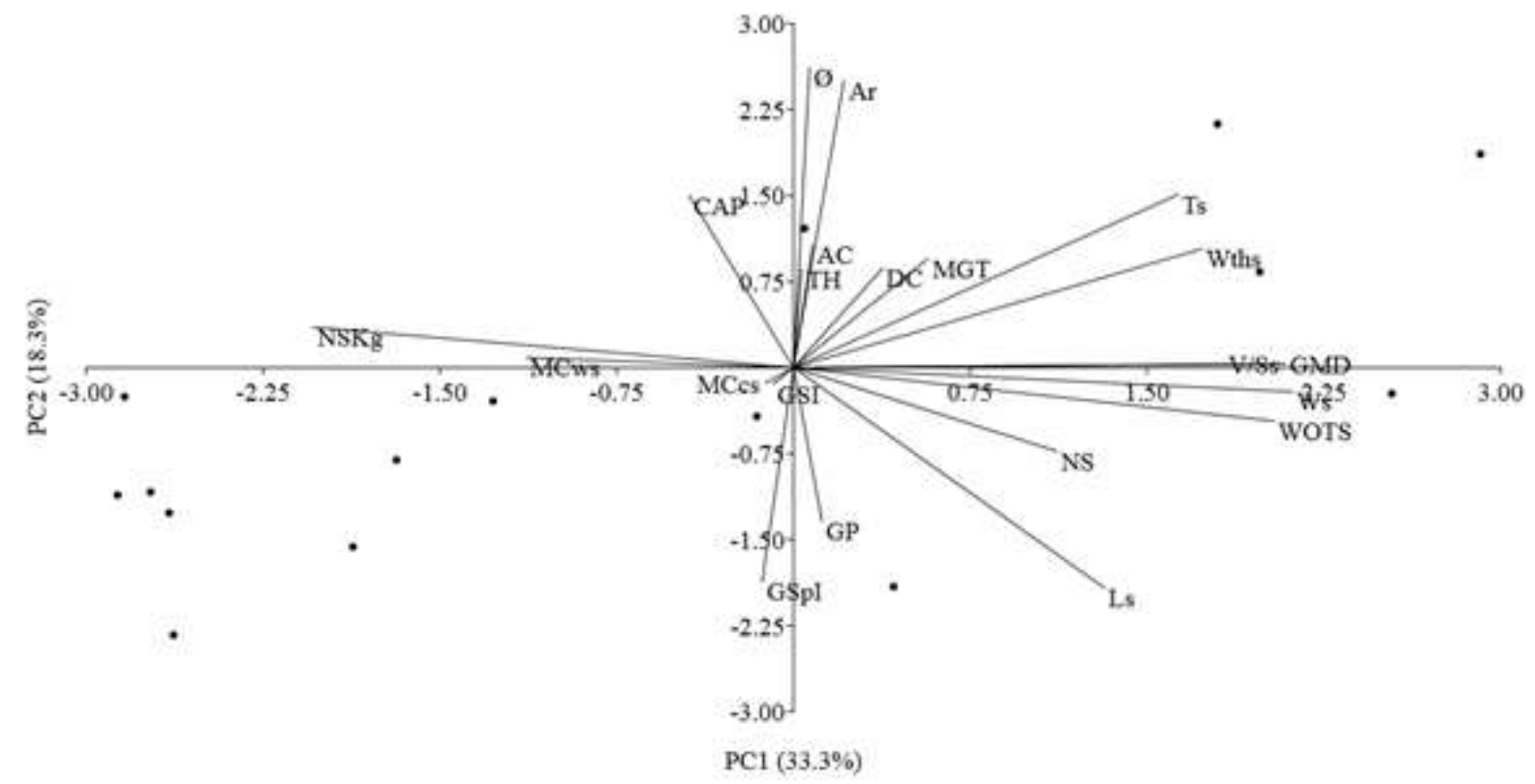

Figure 1 - Eigenvectors, and dispersion obtained in the principal component analysis based on stem circumference (CAP), number of stems (NS), total height (TH), canopy height (AC), canopy diameter (DC), moisture content of whole seeds (MCws), moisture content of cut seeds (MCcs), weight of one-thousand seeds (WOTS), number of seeds per kilo (NS/Kg), weight (Ws), length (Ls), width (Wths), thickness (Ts), germination percentage (GP), mean germination time (MGT), synchronization index (GSI), speed index (GSpI), geometric mean diameter (GMD), seed sphericity (Ø), aspect ratio (Ar), and volume/surface area ratio (V/ Ss) of 20 lots (matrices) of Ormosia discolor.

Figura 1 - Autovetores e plano de dispersão obtidos na análise de componentes principais com base em circunferência do fuste (CAP), número de fustes (NF), altura total (AT), altura da copa (AC), diâmetro da copa (DC), teor de água de sementes inteiras (TUsi), teor de água de sementes cortadas (TUsc), peso de mil sementes (PMS), número de sementes por quilo (NS/Kg), peso (PS), comprimento (Cs), largura (Ls), espessura (Es), porcentagem de germinação (PG), tempo médio (TMG), índice de sincronização $(I S G)$, indice de velocidade (IVG), diâmetro médio geométrico (DMG), esfericidade da semente (Ø), ; relação de aspecto (Ra) e razão volumelárea superficial (V/As) de 20 lotes (matrizes) de Ormosia discolor.

of ranks of the selection index, the 10 matrices/lots with the best performances were selected. Thus, for germinative performance, and in decreasing order of vigor, matrices $2,19,16,9,7,3,12,18,11$, and 5 were selected as the lots with the best physiological potential for this population (Table 2).

Considering the evaluation of dendrometric parameters of the matrices, and technological parameters of the seeds, the matrices with the best results were classified in decreasing order. We highlight matrix 7, which appeared in twelve of the twenty-one parameters evaluated, followed by matrix 16 , and matrix 10 in eight parameters (Table 3 ).

The first two components (PC1 and PC2) were considered oin the principal component analysis, as they manage to retain sufficient amount of the total information contained in the set of original variables for each matrix (Figure 1). The two principal components were able to explain $51.6 \%$ of the variability contained in the observed data. The first component explained $33.3 \%$ (PC1) of the total variability presenting greater loads (Table 4) for the parameters weight, geometric mean diameter, and seed volume/surface area ratio (0.37), followed by the parameter weight of one-thousand seeds (0.36), and number of seeds per kilo (-0.36). The second principal component explained $18.3 \%$ (PC2) of data variability, and presented greater loads the parameters of seed sphericity (0.46), and seed aspect ratio (0.44), followed by the variables seed length $(-0.34)$, and germination speed index (-0.33).

The graphical representation in the principal components allowed to characterize the most representative variables, and with the highest

\section{Revista Árvore 2021;45:e4536}


Table 4 - Correlation coefficients (loads) of the principal components by means of multivariate analysis obtained for dendrometric variables, and technological parameters of twenty matrices of Ormosia discolor.

Tabela 4 - Coeficientes de correlação (cargas) dos componentes principais por meio de análise multivariada obtidos para variáveis dendrométricas e parâmetros tecnológicos de vinte matrizes de Ormosia discolor.

\begin{tabular}{lcr}
\hline Parameters evaluated & PC 1 & PC 2 \\
\hline Stem circumference (CAP) & -0.08 & $0.26^{*}$ \\
Number of shafts & 0.20 & -0.13 \\
Total height (m) & 0.01 & 0.15 \\
Canopy height (m) & 0.01 & 0.19 \\
Canopy diameter $\left(\mathrm{m}^{2}\right)$ & 0.07 & 0.15 \\
Weight of one-thousand seeds (WOTS) & $0.36^{*}$ & -0.08 \\
Number of seeds/kg & $-0.36^{*}$ & 0.06 \\
Water content of cut seed (\%) & -0.02 & -0.02 \\
Water content of whole seed (\%) & -0.20 & 0.02 \\
Weight (g) & $0.37^{*}$ & -0.04 \\
Length (mm) & $0.23^{*}$ & $-0.34^{*}$ \\
Width (mm) & $0.31^{*}$ & 0.18 \\
Thickness (mm) & $0.29 *$ & $0.27^{*}$ \\
Geometric mean diameter (mm) & $0.37^{*}$ & 0.01 \\
Sphericity $\varnothing(\%)$ & 0.01 & $0.46^{*}$ \\
Seed aspect ratio (\%) & 0.04 & $0.44^{*}$ \\
Seed volume/surface area ratio (mm) & $0.37^{*}$ & 0.01 \\
Germination percentage (GP\%) & 0.02 & $-0.24^{*}$ \\
Mean germination time (MGT days) & 0.10 & 0.17 \\
Germination synchronization index (GSI) & -0.01 & -0.03 \\
Germination speed index (GSpI) & -0.02 & $-0.33^{*}$ \\
\hline Eigenvalue & 6.99 & 3.84 \\
\hline Explained variance (\%) & 33.3 & 18.3 \\
\hline * correlations considered in the interpretation of the principal component.
\end{tabular}

* correlations considered in the interpretation of the principal componen
*correlaçóes consideradas na interpretação do componente principal.

correlations (Figure 1 and Table 4). The analysis points to the variables weight, mean geometric diameter of seeds, ratio volume/surface area of seeds, weight of one-thousand seeds, length, width, thickness, and number of stems with the greatest correlations between them, due to the vectors having greater length, and being closer to the $\mathrm{PC} 1$ axis (Figure 1). There are high, and positive correlations between germination variables, and high, and negative correlations between the number of seeds per kilo, and the moisture content of whole seeds with vectors close to the PC1 axis, and in opposite directions.

\section{DISCUSSION}

Biometric studies on phenotypic variations in seeds, and fruits of $O$. discolor have not been found in the literature. According to Cardoso and Meireles (2015), approximately 23 tree species of the genus Ormosia have been identified in the Amazon region.
The species found in the literature with biometric analysis of seeds were $O$. fastigiata, and $O$. arborea, whose seeds have a smooth texture, and bicolor testa similar to the species in this study (Gurski et al., 2012; Silva et al., 2014). The biometric values of these species are similar to those found for $O$. discolor, differing only in the average weight of the seeds, which is lower than that of the aforementioned species.

According to the classification of Brasil (2009), seeds of $O$. discolor fall into the "small" category, although it is common for seeds from the same population to vary in shapes, and sizes that may be correlated with variations in the natural environment of occurrence of the species (Baskin and Baskin, 2014). In biometric analyzes, the low coefficients of variation indicate that the sample has low dispersion, which determines homogeneity, and reliability of the data (Cangussu et al., 2018). However, variations in the homogeneity of data of this nature are common in seeds from different matrices, as each tree reacts differently to environmental factors, which increases the variability in seed shapes (Cangussu et al., 2018). For the biometric data of $O$. discolor there was low dispersion, indicating that the sampling was sufficient for a reliable analysis.

Geometric characteristics derived from the shape of the seeds, such as the geometric mean diameter, sphericity, aspect ratio, and volume/surface area ratio of the seeds, demonstrated to be different using the Scott-Knott test. Although these differences have not been correlated with the variables of seed germinability, these findings may help in the selection of seeds for the storage or production of seedlings aiming at the control of physiological quality. The relations between the shapes of the seeds, in general, are useful for inferences about the amount of nutritional reserve, and the forecast of seedling vigor, since large seeds are normally associated with greater germination, and production of seedlings with greater vigor (Pontes et al., 2018).

The sphericity of seeds based on the isoperimetric properties of a sphere indicates that the higher this value, the closer to a sphere the seed approaches its shape (Pontes et al., 2018; Karaj and Müller, 2010). The species $O$. discolor showed more than $80 \%$ sphericity in each seed lot, and although there are no comparative studies with species of the same genus,

Revista Árvore 2021;45:e4536 
it is a higher value than that found for the species Annona reticulata (L.) Vell., and Jatropha curcas L., which showed $67 \%$, and $56 \%$ sphericity, respectively (Pontes et al., 2018; Karaj and Müller, 2010).

The ratio between seed volume, and surface area is negatively correlated in the principal component analysis with the moisture content analyzed in cut seeds, which is indicated by the presence of vectors close, and in opposite direction to the component 1 axes. Combined analyzes of all parameters are useful for more accurate inferences when analyzing seed lots, and can contribute to the selection of lots with superior characteristics from simple, and easy estimates. In the studies by Zareiforoush et al. (2011), the ratio of volume to surface area were decisive to analyze the drying time, imbibition, and energy requirements of seeds during the germination process.

Another important variable for valuing seed lots is the weight of one-thousand seeds. The results of the WOTS, as well as the number of seeds per kilo are required in the official rules of analysis (Brasil, 2013). These variables are easy to determine, and besides requiring less effort from the analyst, they are also useful for correlating with other seed variables, providing a greater range of information about the physical, and physiological conditions of the lot. Lima Júnior et al. (2014) used the correlation between the weight of one-thousand seeds, and the water content to classify the probable storage behavior of 67 Amazonian species. This methodology facilitates the decision making as to the appropriate manner of storage in unknown species regarding technological parameters. Therefore, it is essential to use appropriate methods to determine the water content of seeds of different species. For $O$. discolor, two subsamples of 23 cut seeds are the most efficient, and indicated method for determining the actual water content of the seeds, as it allowed more water to be removed than in whole seeds at the same temperature, and drying time. The RSA (Brasil, 2009) prescribe the grinding or cutting mainly for large seeds, but they are also indicated for hard-testa seeds.

Physical dormancy due to coat impermeability (Baskin and Baskin, 2014) observed in O. discolor is also useful information for seed technology. Dormancy, although important in ecological terms, is one of the major obstacles in the process of sexual propagation, as it hinders the germinative process of viable seeds, and the uniform production of seedlings even under favorable environmental conditions (Dutra et al., 2013). There are several methods to overcome dormancy in species of the Fabaceae family, among which mechanical, and chemical scarification, and immersion in hot water stand out (Brasil, 2013). In $O$. discolor seeds, the mechanical scarification by cut done properly on the opposite side of the hilum is satisfactory to permeabilize the integument.

On the other hand, the orthodox behavior observed in $O$. discolor is an advantage for the safe storage of seeds. Hard-testa seeds are generally orthodox in nature, tolerate drying, remain alive with water content below 7\%, withstand low temperatures, and can remain viable for many years (Garcia et al., 2011; Hong and Ellis, 1996).

In nature, trees are continuously exposed to various environmental stresses during the different stages of development. Abiotic stresses, such as low, and high temperatures, as well as drought, salt, and oxidative damage are the main factors that impact plant growth (Nelson et al., 2014). However, seeds with high vigor, even in adverse conditions, develop physiological, and biochemical mechanisms to survive, and protect themselves from damage (Carvalho and Nakagawa, 2012). For the tree species Pochota fendleri found throughout the Amazon, the 28-month period in a refrigerator freezer followed by a vigor test, ensured the proper establishment of better-quality stands (Smiderle et al., 2018).

The freeze resistance test, in addition to testing the vigor of $O$. discolor lots, also had considerable control over the preservation of the quality of stored seeds. In the studies by Lima et al. (2014), the method of storage in a cold, and dry chamber preserved the vigor of the seeds for up to 12 months, regardless of the packaging used, in contrast, the vigor of the seeds dropped to 6 months in the natural environment. Other studies that deal with accelerated aging tests for assessing vigor, such as those found in the approaches of Carvalho et al. (2016), are useful for detecting seed vigor under high temperature conditions, and should not be replaced or compared with vigor test on seeds subjected to freezing. On the contrary, the methodologies are complementary, and must be registered as evaluation routines in seed lots. For the species Swietenia macrophylla, the seed vigor can be evaluated by means of the accelerated aging test at 
temperatures of $39{ }^{\circ} \mathrm{C}$ for 96 hours, and $43^{\circ} \mathrm{C}$ for 48 or 96 hours (Carvalho et al., 2016). Although freezing studies have not been found for $S$. macrophylla, they are necessary for the adequate storage of Amazonian seeds, safeguarding the genetic resource for the future.

Another important aspect in the technological analysis of seed lots is the morphological characterization of germination, as it allows to define the characteristic of a normal seedling, and the time in which each germinative event takes place. The germination of $O$. discolor is hypogeal, but its seedling is phanerocotyledonous, that is, the cotyledons are released from the integument, and remain open at the ground. This process lasts an average of 27 days after sowing in scarified seeds; the release of shoot takes time, and only happens after the elongation of the primary root with the beginnings of secondary roots. However, the primary root protrusion occurs on average at four days after sowing, and is the ideal characteristic to evaluate germination in the laboratory. The temperature at $30{ }^{\circ} \mathrm{C}$ was also suitable for germination promoting high percentages ( $>80 \%$ ). For the Amazon species Ormosia excelsa, and Stryphnodendron pulcherrimum, both with impervious coat, the highest germination percentages also occurred at $30{ }^{\circ} \mathrm{C}$ (Tomaz et al., 2018; Santos et al., 2020).

Studies report the influence of fungi in germination tests of forest seeds (Rickli et al., 2014; Berghetti et al., 2015; Pinheiro et al., 2016), with the most common ones being Aspergillus, Penicillium, Trichoderma, and Rizhopus, similar to those identified in los of $O$. discolor. In $S$. pulcherrimum, the endophytic fungi were responsible for the low vigor of the lots, which presented germination percentages around 20\% (Santos et al., 2020). Health quality is also an attribute for assessing the quality of a seed lot. Therefore, it is suggested that phytosanitary studies be carried out on $O$. discolor seeds, since the level of damage, and the nature of fungi, contaminants or endophytes were not computed in this study.

All this information for the same species is only possible in studies that address all stages of the seed production chain, which are gradually being disseminated in the scientific literature, especially with native species from the Amazon (Nascimento Júnior et al., 2016; Tomaz et al., 2018; Santos et al., 2020). From the combination of superior phenotypic characteristics of the matrix plant with the physical, and physiological performance of its seeds, it is possible to mark, and monitor individuals for future generation of seed collection, and planting to meet the demand for forest restoration efficiently. For $O$. discolor, this study enabled to select superior matrices, and lots that should be stored for conservation of the genetic resource, and formation of seed orchards. Seed has been the traditional product of breeding programs. Seed orchards, therefore, must represent an advance, both in the quantity, and quality of seeds (Sweet, 1995).

\section{CONCLUSIONS}

We conclude that all biometric variables are representative for selecting vigorous lots, with emphasis on geometric diameter, surface area, and sphericity of seeds. The matrices $2,19,16,9,7$ showed good germination characteristics concerning to the environmental condition proposed, freezing maintained viability with increased vigor. The matrices 7, 16, and 10 showed superior characteristics for dendrometric, and technological data, being indicated for marking, and phenological monitoring for future collections. A phytosanitary study is recommended for seeds of $O$. discolor, and besides progeny tests to select matrices that produce seeds tolerant to injuries caused by fungi in germination tests carried out in field and laboratory.

\section{AUTHOR CONTRIBUTIONS}

Helinara Lais Vieira Capucho - field data collection, analysis, and interpretation of data and results, bibliographical research, and article writing. Manuel de Jesus Vieira Lima Júnior - conceived the ideas, designed the methodology for the seed technology part, contributed to the review and writing. Angela Maria da Silva Mendes - conceived the ideas, contributed to the structuring of the text, revision of the article. Maria Teresa Gomes Lopes - conceived the ideas, designed the methodology for the genetic analysis part, contributed to the revision and writing. Amazoneida Sá Peixoto Pinheiro - contributed with the analysis and interpretation tools of multivariate statistics, discussion of results. Laerte Nogueira da Silva - contributed financial and logistical support for data collection, writing, and review.

Revista Árvore 2021;45:e4536 


\section{ACKNOWLEDGEMENT}

We thank the Research Support Foundation of the State of Amazonas (FAPEAM) and the National Council for Scientific and Technological Development (CNPq) for the financial support to conduct this study.

\section{REFERENCES}

Abreu SC de, Herrera RC, Menezes MC de, Leão FM, Souza OPS de. Vouacapoua americana aubl. matrix trees in the community forest management plan. Enciclopédia biosfera. 2018;15(28):111-123. doi: 10.18677/EnciBio_2018B10

Araújo Neto JCA, Teixeira JD, Neves MIRS das, Melo LDFA, Ferreira VM. Morphometric characterization, germination and conservation of Triplaris brasiliana Cham. seeds (Polygonaceae). Ciência Florestal. 2018;28(3):949-959. doi: $10.5902 / 1980509833363$

Baskin CC, Baskin JM. Seeds: Ecology, biogeography and evolution of dormancy and germination. San Diego: Academic Press; 2014. ISBN 9780124166776.

Berghetti ALP, Araujo MM, Bovolini MP, Tonetto TDS, Muniz MFB. Seedling morphology and control of pathogens in seeds of Cordia trichotoma. Floresta e Ambiente. 2015;22(1):99-106. doi: 10.1590/21798087.076614

Brasil. Decreto $n^{\circ} 5.153$, de 23 de jul. de 2004 [cited 2020 out 20]. Available from: http://www.planalto. gov.br/ccivil_03/_Ato2004-2006/2004/Decreto/ D5153.htm.

Brasil. Instrução Normativa MAPA n ${ }^{\circ}$ 17, de 26 de abr. de 2017 [cited 2020 out 20]. Available from: https:/www.gov.br/agricultura/pt-br/assuntos/ insumos-agropecuarios/insumos-agricolas/ sementes-e-mudas/publicacoes-sementes-e-mudas/ INN17de28042017comANEXOS.pdf.

Brasil. Lei $\mathrm{n}^{\circ} 10.711$, de 5 de ago. de 2003 [cited 2020 out 20]. Available from: https://www.planalto. gov.br/ccivil_03/leis/2003/110.711.htm.

Brasil. Ministério da Agricultura Pecuária e Abastecimento (MAPA). Regras para Análise de Sementes (RAS). Brasília, Brasil: Secretaria de Defesa Agropecuária; 2009. ISBN 9788599851708.
Brasil. Ministério da Agricultura Pecuária e Abastecimento (MAPA). Instruções para análise de sementes de espécies florestais. Brasília, Brasil: Secretaria de Defesa Agropecuária; 2013.

Brasil. Portaria $n^{\circ} 42$, de 18 de fev. de 2020 [cited 2020 out 20]. Available from: https://in.gov.br/ web/dou/-/portaria-n-42-de-18-de-fevereirode-2020-244800039.

Calvi GP, Ferraz IDK. Levantamento das espécies florestais de interesse econômico e o cenário da produção de sementes e mudas na Amazônia Ocidental. Informativo ABRATES. 2014;24(2):2475.

Cangussu ACV, Caetano APO, Santos JL, Castro Filho MN de, Cardoso AD. Biometric analysis and breaking of dormancy of seeds of Piptadenia viridiflora (Kunth) Benth. Floresta. 2018;48(3):355362. doi: $10.5380 /$ rf.v48i3.55068

Cardoso DBOS, Meireles JE. Ormosia Jacks. in Lista de Espécies da Flora do Brasil. Jardim Botânico do Rio de Janeiro. 2015 [cited 2020 October 27]. Available from: http://floradobrasil.jbrj.gov.br/jabot/ floradobrasil/FB23102.

Carvalho CA de, Silva JB da, Alves CZ.

Accelerated ageing in mahogany seeds. Revista Ciência Agronômica. 2016;47(4):691-699. doi: $10.5935 / 1806-6690.20160083$

Carvalho NM, Nakagawa J. Sementes: ciência, tecnologia e produção. $5^{\mathrm{a}}$. ed. Jaboticabal: Funep; 2012. ISBN: 9788578050900.

Cruz CD. A software package for analysis in experimental statistics and quantitative genetics. Acta Scientiarum. 2013;35(3):271-276. doi: 10.4025/ actasciagron.v35i3.21251

Dutra TR, Massad MD, Sarmento MFQ, Oliveira JC de. Alternative substrates and methods of breaking dormancy for the production of canafístula seedlings. Ceres. 2013;60(1):72-78. doi: 10.1590/S0034737X2013000100011

Garcia LC, Sousa SGA de, Lima RBM de. Seleção de matrizes, coleta e manejo de sementes florestais nativas da Amazônia: Embrapa Amazônia Ocidental, 2011. ISSN 15173135.

\section{Revista Árvore 2021;45:e4536}


Gurski C, Dias ES, Mattos EA. Characters of seeds, seedlings and young plants of Ormosia arboea (Vell.) Harms e Ormosia fastigiata TUL. (Legpapilionoideae). Revista Árvore. 2012;36(1):37-48. doi: 10.1590/S0100-67622012000100005

Hong TD, Ellis RH. A protocol to determine seed storage behaviour. Rome: International Plant Genetic Resources Institute; 1996. ISBN 9290432799

Instituto Nacional de Pesquisas Espaciais - INPE. Plataforma TerraBrasilis: Mapa interativo com polígonos de avisos de evidências de alteração da cobertura floresta na Amazônia Legal e Cerrado. 2020. [cited 2020 out 29]. Available from: http:// terrabrasilis.dpi.inpe.br/app/dashboard/alerts/legal/ amazon/daily/.

Karaj S, Müller J. Determination of physical, mechanical and chemical properties of seeds and kernels of Jatropha curcas L. Industrial crops and products. 2010;32(2):129-138. doi: 10.1016/j. indcrop.2010.04.001

Lima DC, Dutra AS, Camilo JM. Physiological quality of sesame seeds during storage. Revista Ciência Agronômica. 2014a;45(1):138-145. doi: 10.1590/S1806-66902014000100017

Lima Júnior MJV, Hong TD, Arruda YMBC, Mendes AMS, Ellis RH. Classification of seed storage behaviour of 67 Amazonian tree species. Seed Science and Technology. 2014b;42(3):363-392. doi: 10.15258/sst.2014.42.3.06

Moreira FMS, Silva MF da, Faria SM de. Occurrence of nodulation in legume species in the Amazon region of Brazil. New Phytologist. 1992;121(4):563570. doi: 10.1111/j.1469-8137.1992.tb01126.x

Mulamba NN, Mock JJ. Improvement of yield potential of the Eto blanco maize (Zea mays L.) population by breeding for plant traits. Egyptian Journal of Genetics and Cytology. 1978; 7(1):40-51.

Nascimento Júnior LGL do, Lopes MTG, Valente MSF, Martins CC, Colares CRB, Lima Júnior MJV. Estimate of genetic parameters in seeds of Jacaranda copaia (Aubl.) D. Don. Revista de Ciências Agrárias. 2016;59(4):311-319. doi: 10.4322/rca.2153

Nelson GC, Mensbrugghe DVD, Ahammad H, Blanc E, Calvin K, Hasegawa T, et al. Agriculture and climate change in global scenarios: why don't the models agree. Agricultural Economics. 2014;45(1):85-101. doi: 10.1111/agec.12091

Perry DA. The concept of seed vigour and its relevance to seed production techniques. In: Hebblethwaite PD, editor. Seed production. London: Butterworths; 1980. p. 585-591. ISBN 9780408106214

Pinheiro CG, Lazarotto M, Muniz MFB, Redin CG, Santos MV dos. Surface sterilization effect on germination and seeds incidence of fungi of forest species. Pesquisa Florestal Brasileira. 2016;36(87):253-260. doi: 10.4336/2016. pfb.36.87.1234

Pinto ACM, Lima Júnior MJV, Canalez GG, Cunha US. Área de coleta de sementes. In: Lima Júnior MJV, editor. Manejo de sementes para o cultivo de espécies florestais da Amazônia. São Paulo: Editora Brasil Seikyo; 2016. p. 197-209. ISBN 978-85-8252026-0

Pontes MS, Santiago EF, Nobrega MAS, Freitas VMB. Morphologic characterization using linear dimensions on the biometric attributes in seeds of Annona reticulata (L.) Vell. (ANNONACEAE). Ciência Florestal. 2018;28(2):696-707. doi: $10.5902 / 1980509832070$

Rickli HC, Nogueira AC, Koehler HS, ZuffellatoRibas KC. Germination of Vochysia bifalcata under different substrates and temperatures. Floresta. 2014;44(4):669-676. doi: 10.5380/rf. v44i4.33688

Rudd VE. The American species of Ormosia (Leguminosae). Contributions from the U.S. national herbarium. 1965;32(5):279-384.

Santos INL dos, Lopes MTG, Valente MSF, Lima Júnior MJV, Fraxe TJP. Genetic characterization of Stryphnodendron pulcherrimum seeds under different temperature levels. Scientia Forestalis. 2020;48(125):1-12. doi: 10.18671/scifor. v48n125.06

Silva AL da, Dias DCFS, Lima LB de, Morais GA de. Methods for overcoming seed dormancy in Ormosia arborea seeds, characterization and harvest time. Journal of Seed Science. 2014;36(3):318-325. doi: 10.1590/2317-1545v36n31012

Smiderle OJ, Souza AG, Pedroso CÂ, Silva TJ, Souza AA. Correlation between mass and vigor 
of Pochota fendleri (Malvaceae) seeds stored in different environments. Revista de Ciências Agrárias. 2018;41(1):93-99. doi: 10.19084/RCA17221

Sweet GB. Seed orchards in development. Tree physiology. 1995;15(7-8):527-530. doi: 10.1093/ treephys/15.7-8.527

Tomaz JS, Lopes MTG, Valente MSF, Lima Júnior
MJV, Muniz GIB, Rosado SIP. Genetic evaluation of seed germination and development of seedlings in Ormosia excelsa Benth. Floresta. 2018;48(3):331342. doi: 10.5380/rf.v48i3.52799

Zareiforoush H, Hosseinzadeh B, Adabi ME, Motavali A. Moisture-dependent physical properties of paddy grains. Journal of american science. 2011;7(7):175-182. doi: 10.7537/marsjas070711.30 